\title{
Iron deficiency and in vitro iron chelation reduce the expression of cluster of differentiation molecule (CD)28 but not CD3 receptors on murine thymocytes and spleen cells
}

\author{
Solo R. Kuvibidila ${ }^{1 *}$ and Connie Porretta ${ }^{2}$ \\ ${ }^{1}$ Department of Pediatrics, Division of Hematology/Oncology, Box T8-1, Louisiana State University Health \\ Sciences Center, 1542 Tulane Avenue, New Orleans LA 70112, USA \\ ${ }^{2}$ Department of Medicine, Section of Pulmonary Medicine, Louisiana State University Health Sciences Center, \\ 1542 Tulane Avenue, New Orleans LA 70112, USA
}

(Received 21 February 2002 - Revised 11 December 2002 - Accepted 12 February 2003)

\begin{abstract}
Cluster of differentiation molecule (CD)3 and CD28 receptors play crucial roles in T-lymphocyte proliferation. Fe deficiency in man and animals impairs T-lymphocyte proliferation by unknown mechanisms. To test the hypothesis that reduced CD3 and CD28 expression is one of them, thymocytes and splenocytes from control (C; $n$ 24), Fe-deficient (ID; $n$ 24), pair-fed (PF; $n$ 24), and ID mice that were Fe-repleted for $3(\mathrm{R} 3 ; n 24)$ or $14 \mathrm{~d}(\mathrm{R} 14 ; n$ 12) were labelled with anti-CD3-fluorescein isothiocyanate and anti-CD28-phycoerythrin antibodies. Positive cells were analysed by flow cytometry. Significant differences were observed among groups in the mean levels of haemoglobin and liver $\mathrm{Fe}$ stores $(\mathrm{C}=\mathrm{PF}=\mathrm{R} 14>\mathrm{R} 3>\mathrm{ID} ; P<0.005)$. While Fe deficiency slightly increased the percentage of $\mathrm{CD} 3+$ splenocytes, it reduced that of CD28+ thymocytes in mice with thymus atrophy and splenomegaly $(P<0 \cdot 05)$. These changes were corrected by Fe repletion. CD28 mean fluorescence intensity (FI) was lower and CD3 FI was higher in lymphocytes from R3 and ID, especially those with splenomegaly, than in those from R14 and PF mice $(P<0 \cdot 05)$. In vitro Fe chelation by deferoxamine $(60$ min) significantly decreased CD28 expression $(P<0.05)$, and slightly increased that of CD3 $(P>0 \cdot 05)$. Spleen cell proliferative responses to concanavalin $\mathrm{A}$ and anti-CD3 \pm anti-CD28 were reduced by Fe deficiency (ID $\leq \mathrm{R} 3<\mathrm{C}=\mathrm{PF}<\mathrm{R} 14 ; P<0.05$ ); and they correlated with FI and percentages of $\mathrm{CD} 3+$ and $\mathrm{CD} 28+$ cells $(r \leq 0.69 ; P<0.05)$. Indicators of $\mathrm{Fe}$ status negatively correlated with $\mathrm{CD} 3 \mathrm{FI}$ $(r-0.23)$, but positively correlated with CD28 FI $(r \leq 0.44 ; P<0.05)$. Data suggest that altered CD28 expression may contribute to reduced T-cell proliferation during Fe deficiency.
\end{abstract}

Iron deficiency: CD3 and CD28 receptors: Thymus: Deferoxamine: Lymphocyte proliferation

The interaction of an antigen with the T-cell receptor (TCR)-cluster of differentiation (CD)3 complex is necessary, but not sufficient for initiating and sustaining an optimal immune response that leads to clonal expansion, secretion of interleukin-2, and expression of interleukin-2 receptor (Thompson et al. 1989; June et al. 1990, 1994; Harding et al. 1992). In the absence of a co-stimulatory signal, interaction of an antigen with the TCR-CD3 complex may induce anergy and apoptosis (Harding et al. 1992). CD28 is one of the many molecules expressed on $\mathrm{T}$ cells that have been shown to provide the co-stimulatory signal in human subjects and mice (Thompson et al. 1989; June et al. 1990, 1994; Harding et al. 1992; Hathcock et al. 1994). In mice, the CD28 molecule is expressed on all CD4+ and CD8+ T cells from blood, lymph nodes, and 90 to $95 \%$ of thymocytes
(Gross et al. 1992). In man, all CD4+ and about $50 \%$ of CD8+ $\mathrm{T}$ cells from peripheral blood express the CD28 receptor. Fe deficiency, a public health problem in children and women of childbearing age, impairs several immune responses including lymphocyte proliferation in human subjects and laboratory animals (Chandra \& Saraya, 1975; Kemahli et al. 1988; Galan et al. 1992; Looker et al. 1997; Kuvibidila et al. 1998). It also induces thymus atrophy in laboratory animals and perhaps children (Kuvibidila et al. 1983, 2001; Dhur et al. 1991). Although the primary mechanism of impaired lymphocyte proliferation and thymus atrophy associated with $\mathrm{Fe}$ deficiency involves reduced activity of ribonucleotide reductase, the Fe-dependent enzyme required for the biosynthesis of deoxyribonucleotides, other mechanisms related and unrelated to $\mathrm{T}$-cell activation cannot

Abbreviations: anti-CD3, monoclonal antibody raised against cluster of differentiation molecule 3; anti-CD28, monoclonal antibody raised against CD28 molecule; C, control; Con, concanavalin; FITC, fluorescein isothiocyanate; ID, Fe-deficient; PE, phycoerythrin; PF, pair-fed; R, Fe-repleted; TCR, T-cell receptor.

*Corresponding author: Dr Solo Kuvibidila, fax +1 508568 3078, email skuvib@1suhsc.edu 
be excluded (Polson et al. 1990; Furukawa et al. 1992; Haq et al. 1995; Hileti et al. 1995; Kuvibidila et al. 1998, 1999, 2001).

Santos \& De Sousa (1994) reported that the incubation of peripheral blood mononuclear cells obtained from healthy adult volunteers with $100 \mu \mathrm{M}-\mathrm{Fe}$ for $60 \mathrm{~min}$ decreased CD4 levels (expressed as mean intensity of fluorescein isothiocyanate, FITC) by nearly $50 \%$. The same concentrations of $\mathrm{Fe}$ had no effect on the fluorescence intensity of CD2, CD3, or CD8 markers. Neither Zn, a trace element known to affect lymphocyte proliferation and several immune responses, nor $\mathrm{Co}$ or $\mathrm{Ni}$ had any effect on the expression of T-cell markers. However, the concentrations of $\mathrm{Fe}$ used in their experiments were higher than those usually found in serum of healthy (non-Fe-loaded) individuals (Looker et al. 1997). The expression of CD28 marker was not investigated by this group.

The influence of Fe deficiency, a problem more common than Fe overload, on the expression of CD28 and CD3 T-cell markers has not been previously investigated in either human subjects or laboratory animals. Considering that $\mathrm{Fe}$ regulates the biosynthesis and/or functions of many proteins and enzymes involved in T-cell function other than ribonucleotide reductase, it is hypothesized that it may also affect the expression of CD3 and CD28 receptors. The aim of the present study was to test the hypothesis that Fe deficiency alters (reduces) the expression of CD3 and CD28 receptors on murine thymocytes and spleen cells and that the reduction contributes to the impaired lymphocyte proliferative responses to mitogens and antigens (Chandra \& Saraya, 1975; Kuvibidila et al. 1983, 1990, 1998, 1999; Kemahli et al. 1988; Latunde-Dada \& Young, 1992; Kuvibidila \& Porretta, 2002). Specifically, the aims were to determine whether Fe deficiency reduces: (a) the percentage of CD3+ and/or CD28+ thymocytes and spleen cells; (b) the relative levels expressed as fluorescence intensity of these markers.

\section{Methods \\ Source of reagents}

Reagents were received from the following sources: Sigma (St Louis, MO, USA) supplied the haemoglobin standard, deferoxamine, Drabkin's reagents, and Fe assay kits; GIBCO (Grand Island, NY, USA) provided Roswell Park Memorial Institute (RPMI)-1640 with $25 \mathrm{mmol} \mathrm{HEPES} / \mathrm{l}$, and penicillin and streptomycin; Harlan Teklad (Madison, WI, USA) supplied the Fe-deficient (ID) test diet and the deficient diet supplemented with $\mathrm{Fe}$; PharMingen (Costa Mesa, CA, USA) provided monoclonal antibody raised against cluster of differentiation molecule 3 (anti-CD3) conjugated with FITC (anti-CD3-FITC), and monoclonal antibody raised against CD28 molecule (anti-CD28) conjugated with phycoerythrin (PE) (anti-CD28-PE) antibodies.

\section{Experimental design and induction of iron deficiency in mice}

C57BL/6 female mice ( $n$ 108), aged 21-23d, were purchased from Charles River breeding laboratories
(Wilmington, MA, USA). Upon receipt, they were put on an adjustment period for $7 \mathrm{~d}$, during which they received the control diet that contained $50 \mathrm{mg}(0.895 \mathrm{mmol}) \mathrm{Fe} / \mathrm{kg}$ diet in the form of ferrous sulfate and sterile deionized water. Following the adjustment period, mice were randomly assigned to the following dietary treatment groups: control (C; $n$ 24), ID ( $n$ 60), pair-fed (PF; $n$ 24). Fe deficiency was induced by feeding mice a diet that contained only $5 \mathrm{mg}(0.0895 \mathrm{mmol}) \mathrm{Fe} / \mathrm{kg}$. The $\mathrm{C}$ and $\mathrm{PF}$ groups received the same diet except that it was supplemented with $50 \mathrm{mg} \mathrm{Fe} / \mathrm{kg}(0.895 \mathrm{mmol} / \mathrm{kg})$. Except for $\mathrm{Fe}$, the concentrations of protein, fat, carbohydrates, vitamins and minerals of both diets were identical and have been previously reported (Kuvibidila et al. 1998). While $\mathrm{C}$ and ID mice had free access to their diets $24 \mathrm{~h} / \mathrm{d}, \mathrm{PF}$ mice received the control diet in amounts equal to the mean that ID mice had consumed during the preceding $24 \mathrm{~h}$. Mice were housed in sterile microisolator system cages (product 109EI; Laboratory Products, Maywood, NJ, USA) and received sterile deionized water. The lightdark cycle was set for $12 \mathrm{~h}$, and the room temperature at $22^{\circ} \mathrm{C}$. The study was approved by the Institutional Committee for Animal Care and Use of Louisiana State University Health Sciences Center. The feeding period lasted 8 weeks.

\section{Evaluation of iron status at the end of the feeding period}

At 3 and $14 \mathrm{~d}$ before the experiment, thirty-six ID mice with a packed cell volume less than $25 \%$ were given the control diet (Fe repletion protocol (R3, $n$ 24; R14, $n$ 12)). This repletion period was chosen based on our previous experiments that showed that $3 \mathrm{~d}$ were not sufficient to correct indices of Fe status while $14 \mathrm{~d}$ were; but both repletion periods showed significant improvement in T-lymphocyte proliferative responses to mitogens (Kuvibidila et al. 1998). At the time of killing, mice were anaesthetized by diethyl ether inhalation for 30-60 s. After blood was drawn from the retro-orbital plexus, they were killed by cervical dislocation. Haemoglobin and packed cell volume were measured by the cyanmethaemoglobin method and centrifugation, respectively (Rodak, 1992). The $\mathrm{Fe}$ concentrations of the liver and the diets were assayed as have been previously reported (Kuvibidila et al. 1998).

\section{Preparation of single cell suspensions}

Thymuses and spleens were removed under sterile conditions and immediately placed in a pre-weighed sterile culture tube that contained $1 \mathrm{ml}$ wash medium (RPMI1640 supplemented with $25 \mathrm{mmol}$ L-glutamine/l $10 \mathrm{~g}$ bovine serum albumin/l, $50 \mathrm{mg}$ streptomycin/l and $5 \times 10^{4}$ units penicillin/l). After the tubes were weighed, single-cell suspensions were prepared by grinding the thymus or spleen on a nylon mesh attached to a sterile $50 \mathrm{ml}$ beaker secured with a rubber band. The piston of a $3 \mathrm{ml}$ syringe was used to push single cells through the nylon mesh. The nylon mesh was washed with $10 \mathrm{ml}$ serum-free RPMI-1640 and cells were collected into the beaker, and then they were transferred to a $15 \mathrm{ml}$ conical centrifuge tube. Tubes were centrifuged at $400 \mathrm{~g}, 4^{\circ} \mathrm{C}$ for 
10 min. The supernatant fraction was decanted and the pellets were resuspended in ice-cold sterile deionized water $(1 \mathrm{ml})$ to lyse erythrocytes. Tubes were further centrifuged twice under the same conditions. The pellets were then resuspended in wash medium $(2 \mathrm{ml})$. Total and viable cells were counted using a haemocytometer under a light microscope after cells were diluted in a solution of trypan blue $(4 \mathrm{~g} / \mathrm{l})$.

\section{Estimation of the percentage of $\mathrm{CD} 3+$ and $C D 28+$ cells}

Thymocytes and spleen cells $\left(2 \times 10^{6}\right)$ were transferred to a $12 \times 75 \mathrm{~mm}$ plastic culture tube, followed by $500 \mathrm{ng}$ anti-CD3-FITC and 400 ng anti-CD28-PE, in a total volume of $250 \mu \mathrm{l}$ serum-free PBS. Unlabelled anti-CD3 and anti-CD28 antibodies were added to negative controls (or blanks). The final antibody concentrations were 2.0 and $1.6 \mathrm{mg} / \mathrm{l}$ for anti-CD3-FITC and anti-CD28-PE, respectively. Tubes were incubated at $37^{\circ} \mathrm{C}$ for $30 \mathrm{~min}$, protected from light. Cell labelling was performed at $37^{\circ} \mathrm{C}$ instead of $4^{\circ} \mathrm{C}$ because, in a preliminary experiment, it was observed that thymocytes incubated at $37^{\circ} \mathrm{C}$ showed brighter labelling (mean PE fluorescence intensity 111 (SE 12); mean FITC 38 (SE 2)) than those incubated on ice (mean PE 69 (SE 10); mean FITC 33 (SE 1); $n 5$ thymuses). (The percentages of positive cells did not change with temperature (mean 99 (SE 1) v. 99 (SE 0.31)\% CD28+ at 4 and $37^{\circ} \mathrm{C}$, respectively.)

At the end of the incubation period, wash medium $(1 \mathrm{ml})$ was added to each tube before centrifugation at $400 \mathrm{~g}, 4^{\circ} \mathrm{C}$ for $10 \mathrm{~min}$. After a second centrifugation under identical conditions, each pellet was resuspended in $300 \mu \mathrm{l} 4 \%$ $(\mathrm{v} / \mathrm{v})$ formaldehyde solution. Tubes were incubated at room temperature $\left(22^{\circ} \mathrm{C}\right)$ on a shaker (Maxi-Mix III type 6580; Dubuque, IO, USA) set at $200 \mathrm{rpm}$ for $30 \mathrm{~min}$. Fixed cells were analysed within $24 \mathrm{~h}$ on a FACSCALIBUR flow cytometer (Becton Dickinson, Immunocytometry Systems, San Jose, CA, USA) using CELLQUEST Software. An electronic gate based on forward or side scatter was constructed around lymphocyte population. Approximately 5000 events were collected. Four subsets of lymphocytes were identified based on fluorescence intensity on the $\mathrm{X}$ axis (anti-CD3-FITC) and $\mathrm{Y}$ axis (antiCD28-PE): CD3-CD28-, CD3+CD28+, CD3+CD28-, CD3-CD28+. Fluorescence intensity of negative controls was used to define the cut-off points of CD3-CD28- lymphocytes.

\section{Lymphocyte proliferation}

Since thymocytes do not respond to mitogens as well as spleen cells, their mitogenic responses were not studied. Lymphocyte proliferative responses to mitogens were assessed as has been previously reported (Kuvibidila et al. 1998). Briefly, $1 \times 10^{6}$ viable splenic lymphocytes were incubated without or with concanavalin (Con) A $(1.25 \mu \mathrm{g} / \mathrm{ml})$, anti-CD3 antibody $(50 \mathrm{ng} / \mathrm{ml})$, a mixture of Con $\mathrm{A}$ and $50 \mathrm{ng}$ anti-CD28 antibody/ml, or a mixture of anti-CD3 and anti-CD28 antibodies $(50 \mathrm{ng} / \mathrm{ml}$ each) at $37^{\circ} \mathrm{C}, 5 \% \mathrm{CO}_{2}$, in a humidified National Appliance Company incubator. The culture medium contained the following elements of RPMI-1640 (per litre): $50 \mathrm{ml}$ fetal calf serum; $50 \mathrm{mg}$ streptomycin; $5 \times 10^{4}$ units penicillin; $2 \mathrm{mmol} \mathrm{L-glutamine;} 1 \mathrm{mmol}$ sodium pyruvate; $0.1 \mathrm{mmol}$ non-essential amino acids; $50 \mu \mathrm{mol} \beta$-mercaptoethanol. Cells were pulsed with $37 \mathrm{~Bq}$ during the last $24 \mathrm{~h}$ of a $72 \mathrm{~h}$ incubation period. Cells were harvested onto filter strips and the radioactivity incorporated into DNA was estimated by counting in a liquid scintillation counter (LKB 1219; Wallac, Inc., Turku, Finland).

\section{Statistics}

Descriptive statistics (mean values and standard errors of the mean), ANOVA and correlation coefficients were calculated by the use of Microstatistical program (Ecosoft Inc., Indianapolis, IN, USA) as described in the literature (Munro, 1993). When ANOVA detected significant differences among study groups, either Scheffé's test or Student's $t$ test was used to determine which pairs of means were different. The level of significance was set at $P<0 \cdot 05$.

\section{Results}

Indicators of iron status, the weights of body, thymus and spleen

The mean packed cell volume and concentrations of haemoglobin and liver Fe stores of ID mice were significantly lower than those of $\mathrm{C}$ and PF mice (Table $1 ; P<0.05$ ). Fe repletion for $3 \mathrm{~d}$ improved but did not fully correct the decreased indicators. Although Fe repletion for $14 \mathrm{~d}$ corrected the anaemia, liver Fe stores were still below normal when compared with $\mathrm{C}$ and $\mathrm{PF}$ groups (Table $1 ; P<0.05$ ). Mean body weights of ID, R3, and R14 mice were lower than those of $\mathrm{C}$ and PF mice $(P<0.05)$. While both the absolute and relative thymus wet weights were significantly

Table 1. Means of indices of iron status of control (C), pair-fed (PF), and iron-deficient (ID), mice and mice that received the iron-supplemented diet for $3 \mathrm{~d}(\mathrm{R} 3)$ and $14 \mathrm{~d}(\mathrm{R} 14 ; n 12)^{*}$

(Mean values with their standard errors for twenty-four mice per group, except R14)

\begin{tabular}{|c|c|c|c|c|c|c|c|c|c|c|}
\hline \multirow[b]{2}{*}{ Group... } & \multicolumn{2}{|c|}{$\mathrm{C}$} & \multicolumn{2}{|c|}{ PF } & \multicolumn{2}{|c|}{ ID } & \multicolumn{2}{|c|}{ R3 } & \multicolumn{2}{|c|}{$\mathrm{R} 14$} \\
\hline & Mean & SE & Mean & SE & Mean & SE & Mean & SE & Mean & SE \\
\hline Haemoglobin $(g / l)$ & $170 \cdot 7^{a}$ & $2 \cdot 81$ & $170 \cdot 9^{a}$ & 2.96 & $33 \cdot 83^{c}$ & 2.52 & $56 \cdot 66^{\mathrm{b}}$ & 4.68 & $157 \cdot 5$ & $2 \cdot 36$ \\
\hline Packed cell volume (\%) & $50 \cdot 1^{a}$ & 0.4 & $51 \cdot 3^{\mathrm{a}}$ & 0.5 & $16 \cdot 04^{c}$ & 1.02 & $27 \cdot 22^{b}$ & $2 \cdot 1$ & 52.83 & 0.92 \\
\hline Liver Fe $(\mu \mathrm{mol} / \mathrm{g})$ & $0.977^{a}$ & 0.04 & $1 \cdot 111^{\mathrm{a}}$ & 0.06 & $0.221^{c}$ & 0.02 & $0.524^{b}$ & 0.06 & 0.604 & 0.06 \\
\hline
\end{tabular}

\footnotetext{
a,b,c Mean values within a row with unlike superscript letters were significantly different $(P<0.005 ; a>b>c)$.
}

${ }^{\star}$ For details of diets and procedures, see p. 180. 
reduced by Fe deficiency, those of spleen were significantly increased $(P<0 \cdot 001)$. Fe repletion for $14 \mathrm{~d}$, but not $3 \mathrm{~d}$ corrected the weights of both lymphoid organs.

Thymus atrophy (relative thymus weight:body weight $(\mathrm{mg} / \mathrm{g})<2.49$, the lowest value of $\mathrm{C}$ mice) was observed in seventeen of the twenty-four of the ID mice, nineteen of the twenty-four of the R3 mice, and none of the twelve R14 mice. ID mice with thymus atrophy tended to have lower mean haemoglobin concentration (31 (SE 2.67) g/l) than those with normal thymus weight (40.35 (SE 5.22) g/l; $P<0 \cdot 05$ ). Both subgroups did not differ in liver $\mathrm{Fe}$ stores (data not shown). Splenomegaly (relative spleen weight:body weight $(\mathrm{mg} / \mathrm{g})>7.71$, the upper limit observed in $\mathrm{C}$ mice) was observed in sixteen of the twenty-four ID, all of the twenty-four R3, and one of the twelve R14 mice; and it did not significantly affect the mean indicators of $\mathrm{Fe}$ status. The absolute and relative thymocyte numbers were lowest in the ID and highest in R14 mice, and intermediate in $\mathrm{C}, \mathrm{PF}$, and R3 mice (Table 2; $P<0 \cdot 05$ ). As was previously reported (Kuvibidila et al. 1983), despite splenomegaly, the absolute and relative spleen cell numbers were lower in ID and highest in $\mathrm{C}$ and $\mathrm{PF}$ mice $(P<0 \cdot 05)$.

\section{Percentages of $\mathrm{CD} 3+$ and $C D 28+T$ thymocytes}

Four subsets of cells were identified: CD3+CD28+, CD3+CD28-, CD3-CD28+, and CD3-CD28- . Background CD3-FITC and CD28-PE fluorescence intensity of $\mathrm{CD} 3-$ and $\mathrm{CD} 28-$ cells varied from 1.8 to 7.5 . CD3+ and CD28+ cells were defined based on the highest fluorescence intensity of negative cells.

No significant differences were found among groups in the mean percentages of double positive and double negative thymocytes, CD3-/CD28+ (data not shown), or overall percentage of CD3+ thymocytes (Table 3). In contrast, Fe deficiency resulted in a small, but significant increase in the percentage of $\mathrm{CD} 3+\mathrm{CD} 28-$, but a decrease in the overall percentage of CD28+ thymocytes in respect of $\mathrm{C}$ and $\mathrm{PF}$ groups $(P<0.05)$. Thymus atrophy in ID, but not R3 mice, was associated with a significant decrease in the percentage of $\mathrm{CD} 28+$, but an increase in that of $\mathrm{CD} 3+$ thymocytes $(P<0.05)$. Splenomegaly was also associated with a small, though significant, decrease in the percentage of CD28+ thymocytes $(P<0.05)$; but it did not significantly affect that of CD3+ cells. Fe repletion for 3 and $14 \mathrm{~d}$ increased the overall percentage of $\mathrm{CD} 28+$ thymocytes to normal levels.

\section{Percentages of CD3+ and CD28+ spleen cells}

ID mice had mean percentages of double positive, double negative, $\mathrm{CD} 3+\mathrm{CD} 28-$, or $\mathrm{CD} 3-\mathrm{CD} 28+$ spleen cells that were not significantly different from those of other study groups (data not shown). While splenomegaly had no effect on the percentage of CD3+ and CD28+ spleen cells, thymus atrophy was associated with higher percentages of CD3+ (Table 3, P<0.05 compared with PF, R3, and ID mice with normal thymus weight).

\section{Absolute and relative numbers of $C D 3+$ and $C D 28+$ cells}

When compared with normal Fe status, Fe deficiency, but not underfeeding in PF mice, was associated with a significant decrease $(65-70 \%)$ in the absolute (per thymus) and relative (per mg thymus) numbers of CD3+ and CD28+ thymocytes $(P<0 \cdot 05$; Table 4$)$. The decrease is not surprising considering the presence of thymus atrophy in seventeen out of the twenty-four ID mice. Fe repletion for $14 \mathrm{~d}$, but not $3 \mathrm{~d}$, corrected the reduced thymocyte numbers. Both the absolute and relative $\mathrm{CD} 3+$ and $\mathrm{CD} 28+$ spleen cells were lower in ID than in either $\mathrm{C}$ or PF groups $(P<0 \cdot 05)$, and they improved, though were not fully corrected with Fe repletion. Lower numbers of CD3+ and CD28+ cells in spleen from ID mice were due to a reduced number of nucleated cells (Table 2). Lower absolute numbers of CD3+ and CD28+ spleen cells in the R14 group than in the R3 group were due to splenomegaly in the latter group. When spleen weight was taken into consideration, mice in the R14 group had higher CD3+ and CD28+ cells per mg spleen than those from the R3 group $(P<0 \cdot 05)$.

Table 2. Mean weights of body and lymphoid organs, and nucleated cell numbers of control (C), pair-fed (PF), iron-deficient (ID), and ID mice that received the iron-supplemented diet for $3 \mathrm{~d}(\mathrm{R} 3)$ and $14 \mathrm{~d}(\mathrm{R} 14 ; n 12)^{*}$

(Mean values with their standard errors for twenty-four mice per group, except R14)

\begin{tabular}{|c|c|c|c|c|c|c|c|c|c|c|}
\hline \multirow[b]{2}{*}{ Group... } & \multicolumn{2}{|l|}{$\mathrm{C}$} & \multicolumn{2}{|l|}{ PF } & \multicolumn{2}{|c|}{ ID } & \multicolumn{2}{|c|}{ R3 } & \multicolumn{2}{|c|}{$\mathrm{R} 14$} \\
\hline & Mean & SE & Mean & SE & Mean & SE & Mean & SE & Mean & SE \\
\hline Weight $(g)$ & $21 \cdot 11^{\mathrm{a}}$ & 0.45 & $19 \cdot 5^{\mathrm{a}}$ & 0.41 & $17 \cdot 16^{c}$ & 0.44 & $18 \cdot 31^{\mathrm{b}}$ & 0.48 & $17 \cdot 27^{\mathrm{c}}$ & 0.23 \\
\hline Thymus (mg) & $82 \cdot 1^{a}$ & 6.03 & $74 \cdot 2^{a}$ & $3 \cdot 8$ & $39 \cdot 21^{\mathrm{c}}$ & 4.06 & $34 \cdot 2^{\mathrm{b}}$ & $3 \cdot 72$ & 61 & 6.44 \\
\hline Thymus (mg/g body weight) & $3.9^{\mathrm{a}}$ & 0.29 & $3 \cdot 81^{a}$ & 0.2 & $2 \cdot 24^{\mathrm{C}}$ & 0.2 & $1.87^{\mathrm{b}}$ & $0 \cdot 21$ & 3.86 & 0.2 \\
\hline Thymocytes $\left(\times 10^{6}\right)$ & 80.9 & $7 \cdot 39$ & $86 \cdot 62$ & $7 \cdot 76$ & $26 \cdot 63$ & $3 \cdot 83$ & 33.54 & $4 \cdot 26$ & $134.91^{\mathrm{a}}$ & 13.94 \\
\hline Thymocytes ( $\times 10^{6} / \mathrm{mg}$ thymus) & 1.08 & 0.14 & $1 \cdot 25$ & 0.13 & 0.756 & 0.14 & 1.007 & 0.1 & $1.978^{\mathrm{a}}$ & 0.14 \\
\hline Spleen (mg/g body weight) & $4 \cdot 06^{c}$ & 0.21 & $4 \cdot 25^{c}$ & 0.21 & $12 \cdot 4^{\mathrm{b}}$ & 1.49 & $21.99^{a}$ & 2.58 & $5 \cdot 19^{c}$ & 0.38 \\
\hline Splenocytes $\left(\times 10^{6}\right)$ & $48 \cdot 66^{\mathrm{a}}+$ & 3.93 & $44 \cdot 38^{\mathrm{a}}$ & $2 \cdot 6$ & $31 \cdot 17^{c}+$ & $4 \cdot 26$ & $41 \cdot 81^{\mathrm{b}}$ & $4 \cdot 23$ & $32 \cdot 19^{c}$ & 3.023 \\
\hline Splenocytes ( $\times 10^{6} / \mathrm{mg}$ spleen) & $0.578^{\mathrm{a}, \mathrm{b}}+$ & 0.03 & $0.553^{a, b}$ & 0.04 & $0.215^{\mathrm{c} *}$ & 0.6 & $0.137^{c}$ & 0.012 & $0.356^{\mathrm{b}}$ & 0.02 \\
\hline
\end{tabular}

a,b,c Mean values within a row with unlike superscript letters were significantly different $(P<0.05 ; a>b>c)$.

${ }^{*}$ For details of diets and procedures, see p. 180.

† Control mice killed at the same time as the twelve R14 mice had the following mean cell numbers: 32.67 (SE 1.04$) \times 10^{6} / \mathrm{Spleen} ; 0.475(\mathrm{SE} 0.0295) \times 10^{6} / \mathrm{mg}$ spleen. The mean values for ID mice were: 24.25 (SE 3.695) $\times 10^{6} /$ spleen and $0.20($ SE 0.043$) \times 10^{6} / \mathrm{mg}$ spleen. 
Table 3. Percentage of CD3+ and CD28+ thymocytes and splenocytes in control (C), pair-fed (PF), iron-deficient (ID), iron-repleted for $3 \mathrm{~d}$ (R3), and iron-repleted for $14 \mathrm{~d}(\mathrm{R} 14 ; n$ 12) mice, with percentages for sixteen ID mice with splenomegaly (ID+S), eight ID mice without splenomegaly (ID-S), seventeen ID mice with thymus atrophy (ID+TA), and seven ID mice without thymus atrophy (ID-TA)\|

(Mean values with their standard errors for twenty-four mice per treatment group, except R14)

\begin{tabular}{|c|c|c|c|c|c|c|c|c|c|c|c|c|}
\hline \multirow[b]{3}{*}{ Mice } & \multicolumn{6}{|c|}{ Thymus } & \multicolumn{6}{|c|}{ Spleen } \\
\hline & \multicolumn{2}{|c|}{$\begin{array}{l}\text { CD3+ and } \\
\text { CD28- }\end{array}$} & \multicolumn{2}{|c|}{ All CD3+ } & \multicolumn{2}{|c|}{ All CD28+§ } & \multicolumn{2}{|c|}{$\begin{array}{l}\text { CD3+ and } \\
\text { CD28- }\end{array}$} & \multicolumn{2}{|c|}{ All CD3+ } & \multicolumn{2}{|c|}{ All CD28+ } \\
\hline & Mean & SE & Mean & SE & Mean & SE & Mean & SE & Mean & SE & Mean & SE \\
\hline C & 1.58 & 0.33 & $25 \cdot 38$ & 1.99 & $96 \cdot 56^{a}$ & 0.58 & $10 \cdot 5$ & 1.33 & 43.93 & 1.6 & 37.42 & 1.31 \\
\hline $\mathrm{PF}$ & 1.71 & 0.29 & 25.57 & 1.92 & $96 \cdot 32^{\mathrm{a}}$ & 0.51 & $10 \cdot 28$ & 1.47 & 41.03 & 1.91 & 35.58 & 1.13 \\
\hline All ID & $5.49 \dagger$ & 1.91 & 28.67 & 3.4 & $92 \cdot 4^{\mathrm{b}}$ & 2.03 & 13.49 & 2.02 & 46.45 & 3.28 & $36 \cdot 72$ & 2.54 \\
\hline R3 & $2.93 \dagger$ & 0.62 & $26 \cdot 1$ & $2 \cdot 15$ & $95 \cdot 2^{\mathrm{a}, \mathrm{b}}$ & 0.88 & $10 \cdot 2$ & 1.56 & 38.21 & $2 \cdot 21$ & 33 & 1.56 \\
\hline R14 & 2.76 & 0.92 & $25 \cdot 74$ & 1.97 & $95 \cdot 41^{\mathrm{a}, \mathrm{b}}$ & $1 \cdot 16$ & 15.47 & $2 \cdot 27$ & 45.27 & 2.94 & $33 \cdot 19$ & $2 \cdot 81$ \\
\hline ID+S & 6.03 & $2 \cdot 8$ & 26.96 & 4.67 & $91 \cdot 78^{*}$ & 2.94 & $12 \cdot 64$ & 2.73 & $44 \cdot 7$ & 4.69 & 36.88 & 3.58 \\
\hline ID-S & 4.4 & 1.45 & $32 \cdot 11$ & 4.22 & $93 \cdot 76$ & 1.77 & $15 \cdot 9^{\star \star}$ & $3 \cdot 21$ & $48.68^{\star \star}$ & 3.24 & 36.4 & 2.88 \\
\hline ID+TA & $6 \cdot 26$ & 2.67 & $30.71 \ddagger$ & 4.65 & $91.5^{\star}$ & 2.83 & $15 \cdot 64^{\star *}$ & 2.58 & $49 \cdot 37^{\star *}$ & $3 \cdot 16$ & 37.45 & $2 \cdot 18$ \\
\hline ID-TA & 3.6 & 0.84 & 23.74 & 2.39 & 94.73 & 0.97 & 9.1 & 3.06 & 37.45 & $2 \cdot 18$ & 34.95 & $7 \cdot 27$ \\
\hline
\end{tabular}

a,b Mean values with unlike superscript letters were significantly different $(P<0.05)$.

* Mean values were significantly lower than those for the $C$ and PF mice $(P<0.05)$

t Mean values were significantly higher than those for the $C$ and PF mice $(P<0.05)$.

$\ddagger$ Mean value was significantly higher than that for the ID-TA group $(P<0.05)$.

$\S P=0.078$ (ANOVA for the five treatment groups). For all other comparisons, Student's $t$ test was performed.

$\|$ For details of diets and procedures, see p. 180.

${ }^{\star *}$ Mean values were significantly higher than those for the PF and R3 mice $(P<0.05)$.

$C D 3$ and CD28 fluorescence intensity on CD3+ and CD28+ thymocytes

The mean fluorescence intensity of CD3+ and CD28+ thymocytes as well as spleen cells was based on CD3+CD28+, CD3+CD28- and CD3-CD28+, but not all gated cells. There was a small, but significant, difference among groups in mean thymocyte CD28-PE fluorescence intensity $(P<0.05$; Fig. $1(\mathrm{~A}))$. Specifically, CD28 fluorescence intensity of CD3+CD28+ (but not CD3-CD28+) thymocytes was higher in R14 mice than in either R3 or ID mice $(P<0.05)$. Although the mean CD28-PE fluorescence intensity of thymocytes from $\mathrm{C}$, and PF also tended to be higher than that of thymocytes from the overall group of ID mice, the differences were significant only at $P=0.058$ for $\mathrm{PF}$ and $P=0 \cdot 1$ for $\mathrm{C}$. In contrast to what would be expected, thymus atrophy was not associated with reduced CD28 relative levels (Fig. 1 (B)). Instead, ID mice with normal thymus weight had lower mean CD28-PE intensity than those with thymic atrophy or PF mice (Fig. 1 (B); $P<0 \cdot 05$ ). ID mice with splenomegaly had lower CD28-PE intensity than either those without splenomegaly $(P>0.05), \mathrm{R} 14 \quad(P<0.05)$, or $\mathrm{PF}$ mice $(P=0 \cdot 065$; Fig. $2(\mathrm{C}))$.

In contrast to CD28, CD3-FITC fluorescence intensity of $\mathrm{CD} 3+\mathrm{CD} 28+$ thymocytes tended to be higher in ID

Table 4. Absolute and relative CD3+ and CD28+ cell numbers in spleen and thymus for control (C), iron-deficient (ID), pair-fed (PF), iron-repleted for $3 \mathrm{~d}(\mathrm{R} 3)$, and iron-repleted for $14 \mathrm{~d}(\mathrm{R} 14 ; n$ 12) mice†

(Mean values with their standard erors for twenty-four mice group, except R14)

\begin{tabular}{|c|c|c|c|c|c|c|c|c|}
\hline & \multicolumn{4}{|c|}{ Thymus } & \multicolumn{4}{|c|}{ Spleen } \\
\hline & \multicolumn{2}{|c|}{ CD3+ } & \multicolumn{2}{|c|}{ CD28+ } & \multicolumn{2}{|c|}{ CD3+ } & \multicolumn{2}{|c|}{ CD28+ } \\
\hline & Mean & SE & Mean & SE & Mean & SE & Mean & SE \\
\hline \multicolumn{9}{|c|}{ No. of cells $\left(\times 10^{7} /\right.$ thymus or spleen) } \\
\hline C & $2 \cdot 07^{\mathrm{b}}$ & 0.26 & $7 \cdot 83^{b}$ & 0.73 & $2 \cdot 1^{\mathrm{a}}$ & $0 \cdot 15$ & $1 \cdot 83^{\mathrm{a}}$ & 0.16 \\
\hline PF & $1.96^{\mathrm{b}}$ & $0 \cdot 17$ & $8 \cdot 35^{\mathrm{b}}$ & 0.76 & $1.82^{\mathrm{a}}$ & 0.12 & $1.57^{\mathrm{a}}$ & 0.104 \\
\hline ID & $0.723^{\mathrm{c}}$ & $0 \cdot 11$ & $2 \cdot 51^{\mathrm{c}}$ & 0.37 & $1 \cdot 32^{\mathrm{c}}$ & 0.14 & $1.08^{\mathrm{C}}$ & 0.11 \\
\hline R3 & $0.802^{\mathrm{c}}$ & 0.31 & $3 \cdot 18^{\mathrm{c}}$ & 0.43 & $1.613^{\mathrm{b}}$ & 0.28 & $1 \cdot 39^{\mathrm{b}}$ & 0.16 \\
\hline R14 & $3 \cdot 31^{\mathrm{a}}$ & 0.31 & $12 \cdot 97^{\mathrm{a}}$ & 1.44 & $1.393^{\mathrm{C}}$ & $0 \cdot 11$ & $1.03^{\mathrm{C}}$ & 0.11 \\
\hline \multicolumn{9}{|c|}{ No. of cells $\left(\times 10^{7} / \mathrm{mg}\right.$ thymus or spleen $)$} \\
\hline C & $0.293^{\mathrm{b}}$ & 0.048 & $1.088^{\mathrm{b}}$ & 0.013 & $0.251^{\mathrm{a}}$ & 0.001 & $0.218^{\mathrm{a}}$ & 0.001 \\
\hline PF & $0.285^{\mathrm{b}}$ & 0.03 & $1.206^{\mathrm{b}}$ & 0.012 & $0.228^{\mathrm{a}}$ & 0.0018 & $0.196^{\mathrm{a}}$ & 0.0015 \\
\hline ID & $0.208^{\mathrm{b}, \mathrm{c}}$ & 0.037 & $0.659^{c}$ & 0.101 & $0.095^{\mathrm{c}}$ & 0.022 & $0.072^{\mathrm{c}}$ & 0.016 \\
\hline R3 & $0.279^{b}$ & 0.04 & $1.01^{\mathrm{b}}$ & $0 \cdot 10$ & $0.055^{\mathrm{c}}$ & 0.078 & $0.047^{c}$ & 0.066 \\
\hline R14 & $0.493^{\mathrm{a}}$ & 0.035 & $1.899^{\mathrm{a}}$ & 0.144 & $0.159^{\mathrm{b}}$ & 0.012 & $0.118^{\mathrm{b}}$ & 0.012 \\
\hline
\end{tabular}



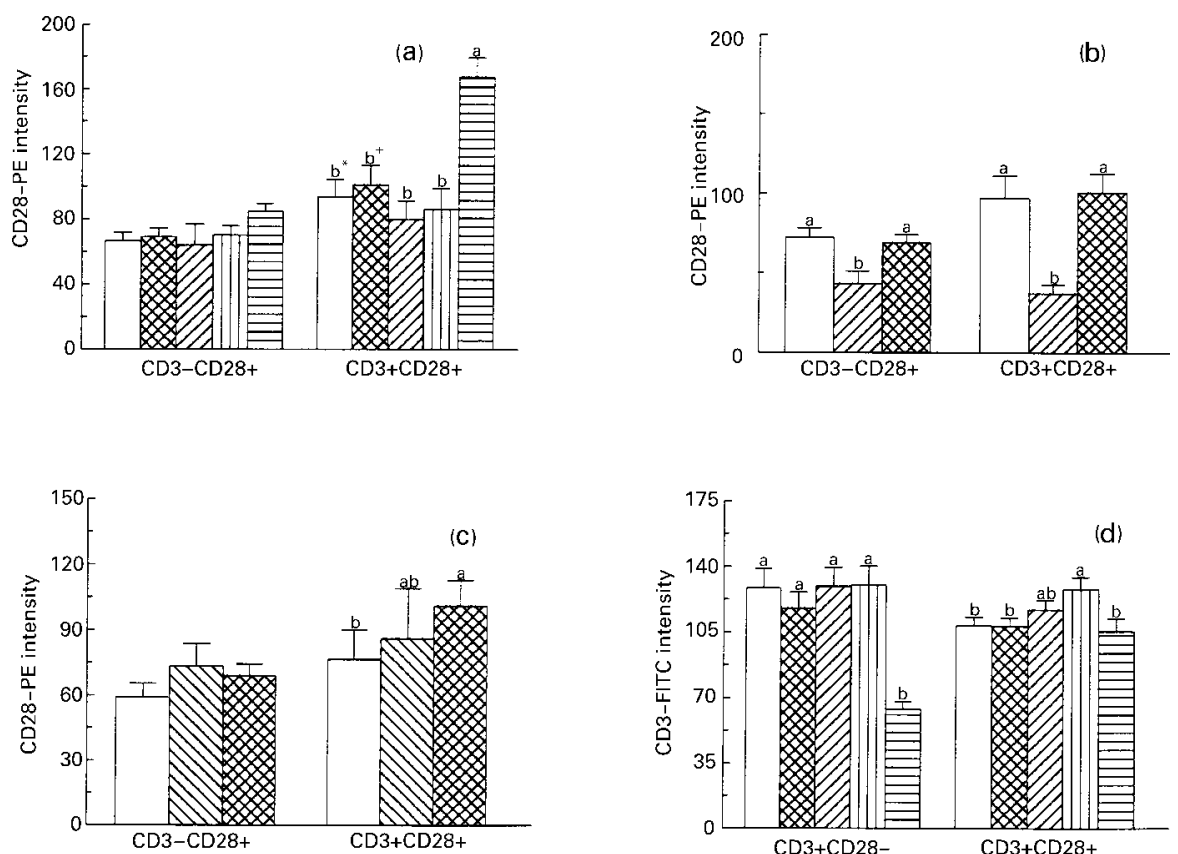

Fig. 1. (a), CD28-phycoerythrin (PE) fluorescence intensity of thymocytes from control (C; $\square$ ), pair-fed (PF; 㒳), Fe-deficient (ID; $\mathbb{Z}$ ), ID that were Fe-repleted for 3d (R3; 四) or 14d (R14; 目) mice. Each group had twenty-four mice except for R14 that had twelve. (b), CD28-PE fluorescence intensity of thymocytes from ID mice with thymus atrophy $(\square ; n 17)$, ID mice with normal thymus weight (囚; $n 7$ ), and PF mice (网; $n$ 24). (c), CD28-PE fluorescence intensity of thymocytes from ID mice with splenomegaly ( $\square ; n$ 16), ID mice without splenomegaly (with normal spleen weight) ( $\mathbb{\nabla} ; n$ 8), and PF mice (网; $n$ 24). (d), CD3-fluorescein isothiocyanate (FITC) fluorescence intensity of thymocytes from $C(\square)$, PF $(\otimes)$, ID $(\mathbb{Q})$, R3 $(\mathbb{W})$ or R14 (目) mice. Each group had twenty-four mice except for R14 that had twelve. Mean values are shown, with standard errors represented by vertical bars. ANOVA was performed on decimal logarithms of fluorescence intensity. ${ }^{a, b}$ Within each subset of thymocytes, mean values with unlike letters were significantly different $(P<0.05, a>b) ; b^{*} P=0.058$ (ID compared with $\left.P F\right)$; $\mathrm{b}^{+} P=0.1$ (ID compared with C).
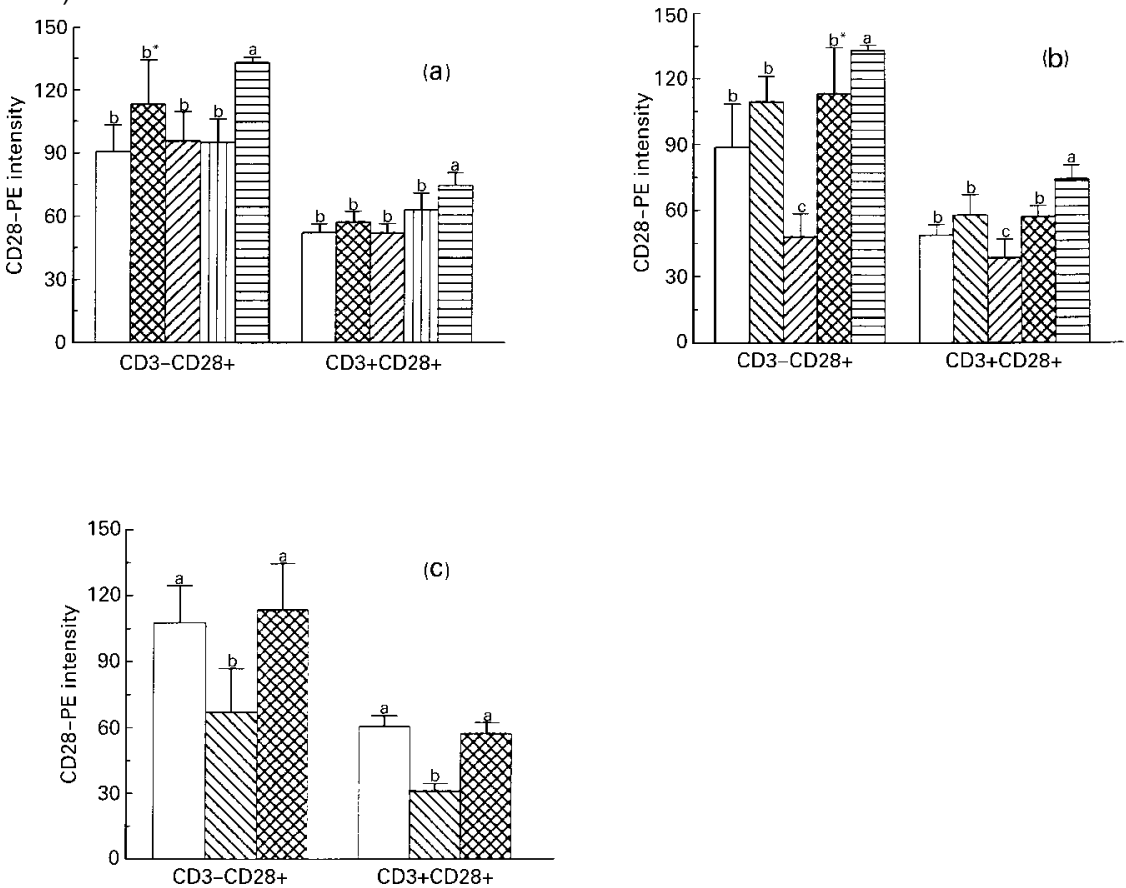

Fig. 2. (a), CD28-phycoerythrin (PE) fluorescence intensity of double positive and single positive spleen cells from control ( $\square$ ), pair-fed (PF; $\otimes)$, Fe-deficient (ID; $\mathbb{Z})$, ID that were Fe-repleted for $3 \mathrm{~d}(\mathbb{\mathbb { W }})$ or $14 \mathrm{~d}(\mathrm{R} 14$; 目) mice. Each group had twenty-four mice except for R14 that had twelve. The decimal logarithms of fluorescence intensity were compared by Student's $t$ test. (b), CD28-PE fluorescence intensity of double positive and single positive spleen cells from ID mice with splenomegaly $(\square ; n 16)$, ID mice without splenomegaly (with normal spleen weight)

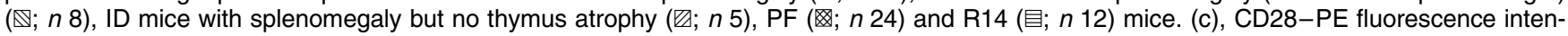
sity of double positive and single positive spleen cells from ID mice with thymus atrophy ( $\square ; n$ 17), ID mice with normal thymus weight ( $\mathbb{\nabla} ; n 7$ ), and PF mice (ख $n$ 24). Mean values are shown, with standard errors represented by vertical bars. ${ }^{a, b, c}$ Within each subset of spleen cells, mean values with unlike letters were significantly different $(P<0.05, a>b>c) ; b^{*}$ mean values were significantly lower than those denoted by $a$ $(P=0.059)$. 
$(P>0.05)$ and R3 $(P<0.05)$ mice than in those from R14 mice (Fig. 1 (D)). The same trend was observed when ID and $\mathrm{R} 3$ were compared with $\mathrm{C}$ and $\mathrm{PF}$, but the difference was significant only with R3 $(P<0.05)$. Although CD3-FITC intensity of CD3+CD28 - thymocytes was not different between $\mathrm{C}$, ID, and $\mathrm{R} 3$ mice, it was significantly lower in those from R14 mice $(P<0 \cdot 05)$. Thymus atrophy and splenomegaly were associated with a nonsignificant increase (17 and $25 \%$ respectively) in mean CD3-FITC intensity (no data shown).

\section{CD3 and CD28 fluorescence intensity in CD3 + and CD28+ spleen cells}

Mean CD28-PE fluorescence intensity tended to be higher in spleen cells from R14 mice than in those from the other four study groups (Fig. 2 (A); $P<0.05$ compared with ID and R3 mice). However, no significant difference was observed between the overall ID group and either C, PF or R3 groups. Splenomegaly, especially in ID mice with normal thymus weight, was associated with a significant decrease in CD28-PE fluorescence intensity when compared with cells obtained from PF and R14 mice (Fig. 2 (B), $\quad P=0.022$ for $\mathrm{CD} 3+\mathrm{CD} 28+$ and $P=0.057$ for CD3 - CD28+ PF cells, $P<0.001$ for double positive and single positive R14 cells). In contrast to splenomegaly, thymus atrophy was not associated with reduced CD28-PE fluorescence intensity. Instead, as with thymocytes, spleen cells obtained from ID with normal thymus weight showed significantly lower CD28-PE fluorescence intensity than in those from ID with thymus atrophy, C,
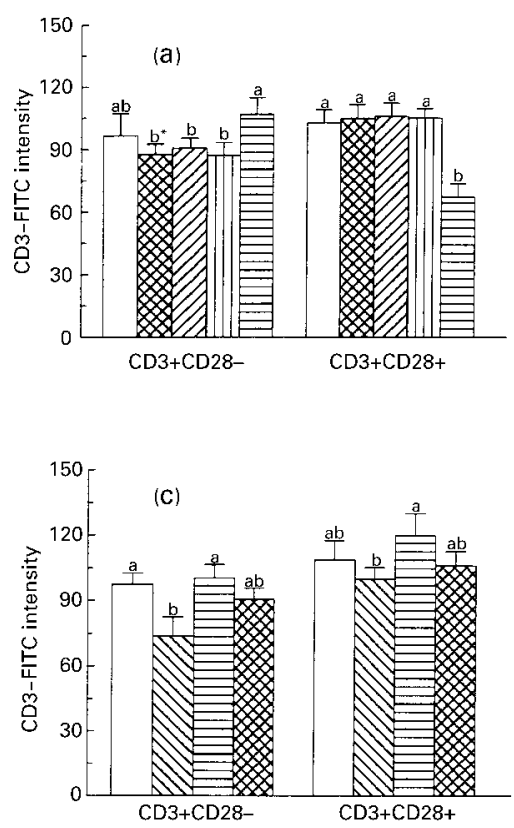

PF, and R14 mice (Fig. 2 (C); $P<0.05$, compared with Fig. 2 (A)).

When the overall group of ID mice was used in statistical analysis, no significant differences were found between $\mathrm{C}$, ID, PF and R3 groups in CD3-FITC intensity of double positive and single positive spleen cells (Fig. 3 (A)). However, mean CD3-FITC intensity was higher in CD3+CD28 - but lower in CD3+CD28+ cells from R14 mice than in those from mice from the other study groups $(P<0 \cdot 05)$. Both splenomegaly and thymus atrophy tended to be associated with higher CD3-FITC when compared with ID mice without these abnormalities; but the trend was significant only for thymus atrophy $(P<0.05$; Fig. 3 (B) and (C)). Spleen cells obtained from ID mice with normal thymus weight had significantly lower mean CD3-FITC intensity than those from PF $(P=0 \cdot 08), \mathrm{C}$ and R14 mice $(P<0 \cdot 05 ; \mathrm{CD} 3+\mathrm{CD} 28-$ cells only, compared with Fig. $3(\mathrm{~A}))$.

\section{Effects of iron chelation on the expression of CD3 and CD28 molecules}

To further elucidate the possible influence of $\mathrm{Fe}$ on the expression of both CD3 and CD28 markers, thymocytes obtained from normal (Fe-sufficient) mice were incubated without and with deferoxamine for either 60 or $120 \mathrm{~min}$ as described by Kuvibidila et al. (1999). This pilot study was conducted because it is nearly impossible to completely deplete $\mathrm{Fe}$ from spleen cells or thymus in vivo. At both incubation periods, Fe chelation resulted in a significant decrease in $\mathrm{CD} 28-\mathrm{PE}$ fluorescence intensity in

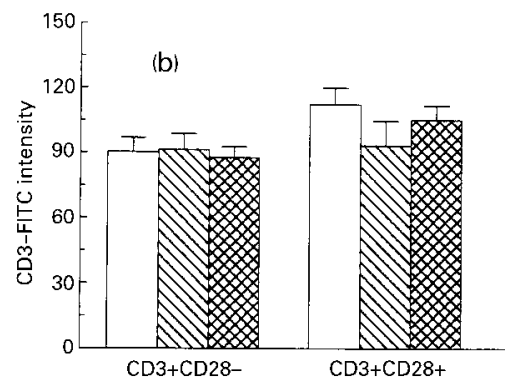

Fig. 3. (a), CD3-fluorescein isothiocyanate (FITC) fluorescence intensity of spleen cells from control ( $\square$ ), pair-fed (PF; $\otimes)$, Fe-deficient (ID; $\square)$, ID that were Fe-repleted for $3 \mathrm{~d}(\mathrm{~m})$ or $14 \mathrm{~d}$ (R14; 目) mice. Each group had twenty-four mice except for R14 that had twelve. (b), CD28-FITC fluorescence intensity of spleen cells from ID mice with splenomegaly ( $\square$; $n$ 16), ID mice without splenomegaly (with normal spleen weight) $(\mathbb{\nabla} ; n$ 8), and PF mice (国; $n$ 24). (c), CD28-FITC fluorescence intensity of spleen cells from ID mice with thymus atrophy ( $\square$; $n$ 17), ID mice with normal thymus weight ( $\mathbb{\nabla} ; n 7)$, ID mice with both splenomegaly and thymus atrophy (目; $n 11)$ and PF mice (国; $n$ 24). Mean values are shown, with standard errors represented by vertical bars. Statistical analysis was performed on decimal logarithms of fluorescence intensity. a,b Within each subset of spleen cells, mean values with unlike letters were significantly different $(P<0.05, a>b)$. 
CD3+CD28+ and CD3-CD28+ thymocytes in a dosedependent fashion $(P<0.05$; Fig. 4 (A) for $60 \mathrm{~min}$ (data not shown for $120 \mathrm{~min}$ )). As for the in vivo $\mathrm{Fe}$ deficiency, $\mathrm{Fe}$ chelation tended to increase the fluorescence intensity of CD3+ thymocytes $(P=0 \cdot 1$; Fig. 4 (B) for $60 \mathrm{~min}$ (data not shown for $120 \mathrm{~min})$ ). Fe chelation by deferoxamine for 60 and $120 \mathrm{~min}$ did not significantly change the percentages of any of the four subsets of thymocytes (data not shown).

\section{Lymphocyte proliferative responses to mitogens}

Significant differences were observed among groups in splenic lymphocyte proliferative responses to Con A and anti-CD3 (Fig. 5 (A); $P<0 \cdot 05$ ). While stimulation indices were not significantly different between C, PF and R14 groups, the three groups showed higher indices than both ID and R3 groups $(P<0.05)$. In contrast to our previous observation (Kuvibidila et al. 1999), there were no differences in mean indices of ID and R3, in part because of the limited concentration of fetal calf serum $(5 \%$ instead
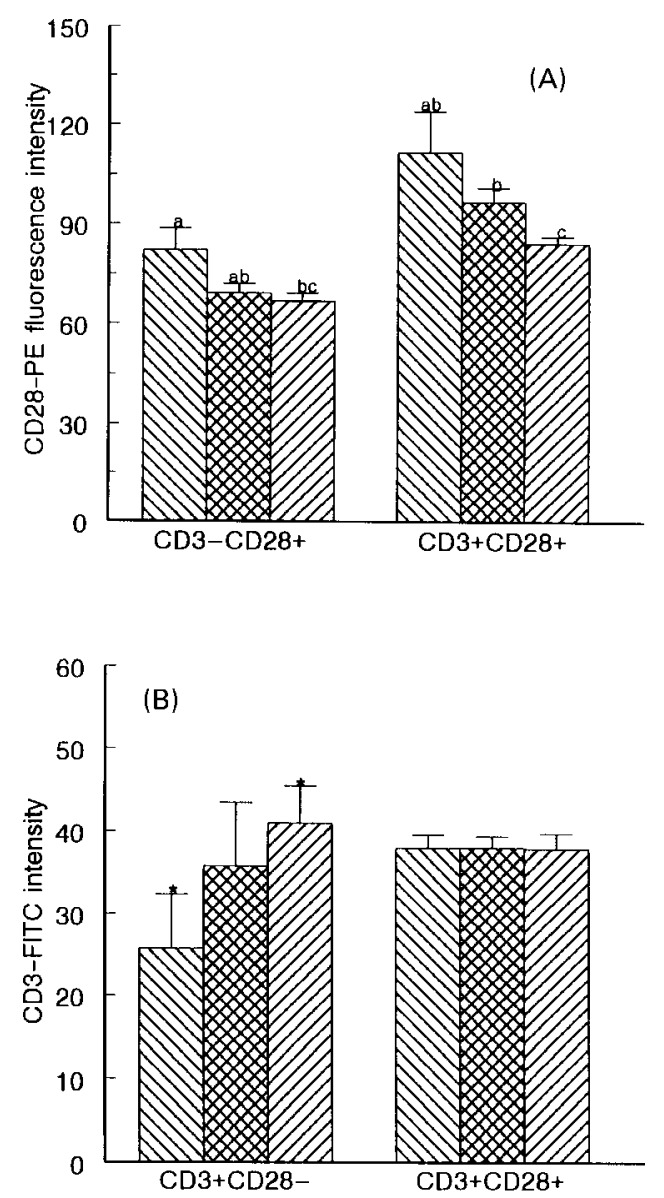

Fig. 4. Effects of Fe chelation by deferoxamine $(0(\mathbb{\nabla}), 10(\mathbb{x})$, or $100(\mathbb{Q}) \mu \mathrm{g} / \mathrm{ml})$ for $60 \mathrm{~min}$ on the expression of CD28 (A) and CD3 (B) receptors on thymocytes from normal (control) mice. Mean values are shown for five mice per group, with standard errors represented by vertical bars. ${ }^{a, b, c}$ Within each thymocyte subset, mean values with unlike letters were significantly different $(P<0.05, \mathrm{a}>\mathrm{b}>\mathrm{c})$; ${ }^{*} P=0.1$. PE, phycoerythrin; FITC, fluorescein isothiocyanate. of $10 \%$ ) that was used in the current study. The addition of anti-CD28 antibody to Con A- and anti-CD3-activated cultures increased lymphocyte proliferative responses in all groups, but the differences between ID and the other study groups persisted $(P<0 \cdot 05)$. In parallel with lower CD28-PE intensity, spleen cells from ID mice with splenomegaly showed significantly lower proliferative responses to these mitogens than those obtained from ID with normal spleen weight (Fig. 5 (B); $P<0.05$ ). Conversely, spleen cells obtained from ID mice without splenomegaly had proliferative responses that were not significantly different from those of $\mathrm{C}$ (and $\mathrm{PF}$ ) mice. Also in agreement with higher CD28-PE intensity, ID mice with thymus atrophy had higher proliferative responses to mitogens than those without thymus atrophy (Fig. 5 (B); $P<0 \cdot 05$ ).
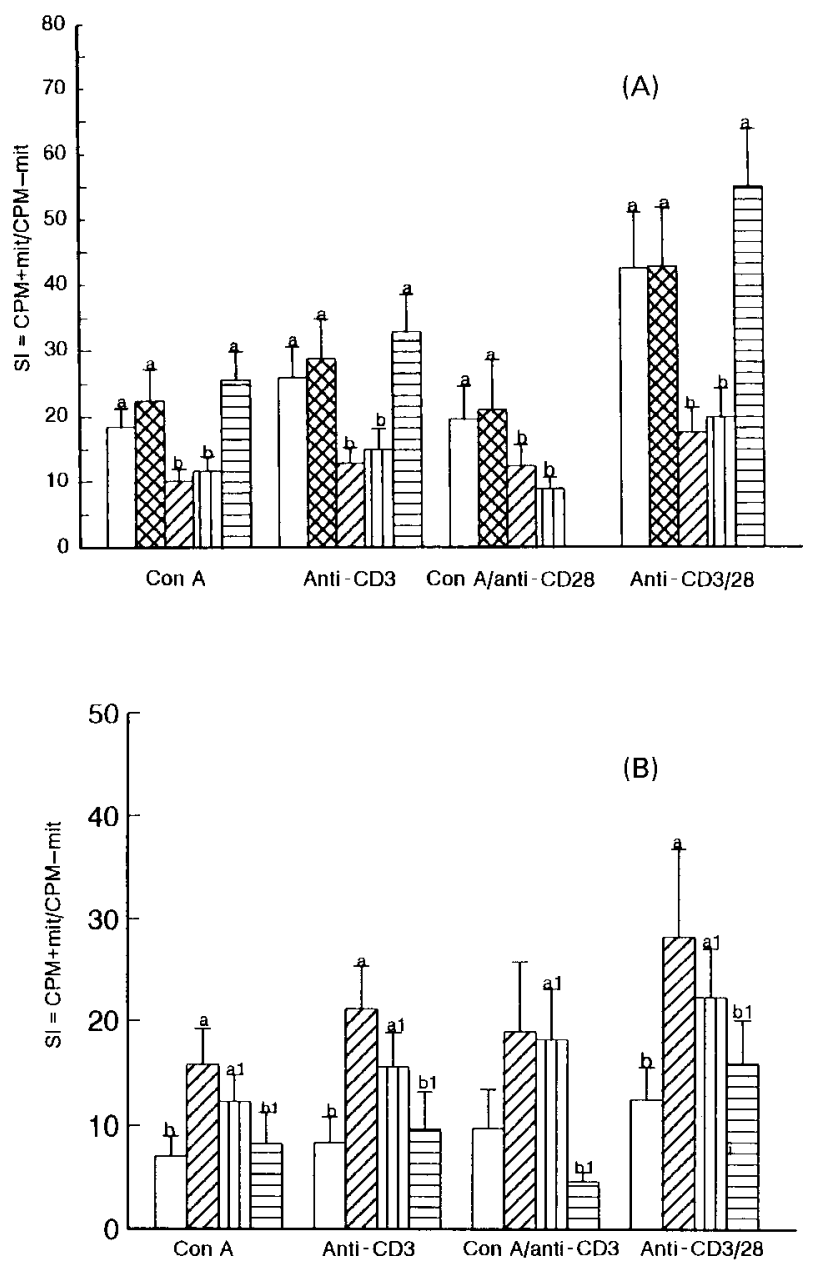

Fig. 5. (A), Splenic lymphocyte proliferative responses to mitogens in control $(\square)$, pair-fed (ख), Fe-deficient (ID; $\mathbb{Z})$, ID that were Ferepleted for $3 \mathrm{~d}(\mathbb{W})$ or $14 \mathrm{~d}(\mathrm{R} 14$; 目) mice. Each group had twentyfour mice except for R14 that had twelve. (B), Splenic lymphocyte proliferative responses to mitogens in ID mice with splenomegaly ( $\square ; n 16)$, ID mice without splenomegaly (ख; $n 8)$, ID mice with thymus atrophy (ख; $n 17)$, and ID mice without thymus atrophy (目; $n 7$ ). Results (mean values with their standard errors represented by vertical bars) are expressed as stimulation indexes $(\mathrm{SI})=\mathrm{CPM}+$ mitogen (mit)/CPM-mit. ${ }^{a, b}$ For each mitogen, mean values with unlike letters were significantly different $(\mathrm{a}>\mathrm{b} ; \mathrm{a} 1>\mathrm{b} 1 ; P<0.05)$. CPM, counts per minute; Con, concanavalin. 


\section{Correlation coefficients}

In the thymus, indices of $\mathrm{Fe}$ status negatively and significantly correlated with the percentages of $\mathrm{CD} 3+$ cells as well as CD3-FITC intensity $(r-0.21$ to $-0 \cdot 267, P<0.05$; data not shown). Conversely, indicators of Fe status positively and significantly correlated with the percentages and fluorescence intensity of CD28+ thymocytes $(r \leq 0.281 ; P<0.05)$. In the spleen, indices of $\mathrm{Fe}$ status positively and in most cases significantly correlated with the percentage of CD28+ cells and CD28-PE intensity (Table $5 ; P<0 \cdot 05$ ). As expected from data of Table 3 and Fig. 3, indices of Fe status negatively correlated with the percentage of $\mathrm{CD} 3+$ spleen cells as well as CD3-FITC intensity $(P<0 \cdot 05)$. Lymphocyte proliferative responses to mitogens positively, and often significantly, correlated with the percentages of CD3+ and CD28+ spleen cells, as well as CD28-PE fluorescence intensity $(P<0 \cdot 05)$. However, CD3-FITC intensity positively and significantly correlated with lymphocyte proliferative responses to mitogens only when anti-CD28 antibody was added to the culture medium.

\section{Discussion}

In vertebrates, the thymus is the main lymphoid organ where T-cell maturation takes place. The maturation processes involves gene rearrangement, acquisition and loss of the expression of various T-cell markers (TCR, CD2, CD3, CD4, CD8, CD28) (Turka et al. 1991). These various markers have been shown to regulate the nature and degree of T-cell activation and function. CD3 and CD28 markers are of particular interest because the former is crucial for $\mathrm{T}$-cell activation, and the latter determines the capacity of activated $\mathrm{T}$ cells to proliferate, secrete cytokines and exert effector functions (Thompson et al. 1989; Turka et al. 1990; Shahinian et al. 1993).

In the present study, it was observed that in vivo $\mathrm{Fe}$ deficiency slightly, but significantly, decreased the expression of CD28 marker (per cell) and the percentage of CD28+ thymocytes especially in mice with splenomegaly and/or thymus atrophy. In contrast to our hypothesis, in vivo Fe deficiency did not decrease either the percentage or relative levels of $\mathrm{CD} 3+$ thymocytes. In fact, $\mathrm{Fe}$ deficiency tended to increase the percentage of CD3+CD28 - thymocytes and CD3 relative levels of $\mathrm{CD} 3+\mathrm{CD} 28+$ thymocytes. Our results on a trend of decreased CD28 expression but increased CD3 expression were confirmed in an in vitro model of Fe deficiency. The changes in CD3 and CD28 expression were probably not due to underfeeding because they were not observed in PF mice. The temperature $\left(37^{\circ} \mathrm{C}\right)$ at which thymocytes were labelled with antibodies also is probably not responsible for the differences between deficient and control mice because the effect of Fe deprivation (chelation) on CD28 expression persisted when cells were incubated at $4^{\circ} \mathrm{C}$ (preliminary study). The percentages of CD28+ thymocytes that were observed in $\mathrm{C}$ and $\mathrm{PF}$ mice are similar to those previously reported for normal mice (Havran et al. 1987; Gross et al. 1992). The mean percentage of CD3+ thymocytes of $\mathrm{C}$ (PF and R14) mice (25\%) was only slightly higher than the $18 \%$ that has been previously reported by other investigators (Havran et al. 1987).

The effect of Fe deficiency on CD28 expression was not limited to the thymus, but it was also observed in the spleen. When compared with mice that were Fe repleted for $14 \mathrm{~d}$, spleen cells obtained from ID mice, especially those with splenomegaly, showed significantly lower CD28-PE fluorescence intensity (Fig. 2 (B)). Interestingly, spleen cells as well as thymocytes obtained from ID mice with normal thymus weight showed lower CD28-PE fluorescence intensity than those with thymus atrophy. Although the reason for such an effect is obscure, it can be speculated that during the development of Fe deficiency, there is a selective loss (perhaps arrest in maturation process, increased apoptosis, or reduced proliferation) of a subset of pre-T cells that would normally express high levels of CD28 receptor. Perhaps when Fe deficiency is not very severe, thymocytes with low levels of CD28 prematurely exit the thymus and home in the spleen. However, when Fe deficiency is more severe and chronic, only thymocytes, which express higher levels of CD28, survive, proliferate and exit the thymus to home in peripheral organs including the spleen. Another possible explanation could be a confounding effect of undernutrition. Thymus atrophy is very common in malnourished laboratory

Table 5. Correlation coefficients between lymphocyte proliferative responses, liver iron levels, and expression of CD3 and CD28 on spleen cellst

(Values based on all the studied mice; $n 108$ )

\begin{tabular}{|c|c|c|c|c|c|c|c|}
\hline & Haemoglobin & Packed cell volume & $\mathrm{Fe}$ & Con A & Anti-CD3 & Con $A$ anti-CD28 & $\begin{array}{c}\text { Anti-CD3 and } \\
\text { anti-CD28 }\end{array}$ \\
\hline \% CD3-CD28+ & -0.194 & $-0.203^{\star}$ & -0.047 & $-0.297^{*}$ & $-0.214^{*}$ & $-0.282^{*}$ & $-0.433^{*}$ \\
\hline$\%$ CD3+CD28+ & 0.1 & 0.03 & -0.056 & $0.177^{\star}$ & 0.135 & $0.513^{*}$ & $0.174^{\star}$ \\
\hline$\%$ CD3+CD28- & $-0.266^{*}$ & $-0.27^{\star}$ & -0.094 & $0.331^{*}$ & $0.441^{*}$ & 0.129 & $0.69^{\star}$ \\
\hline All CD3+ & -0.115 & 0.09 & -0.11 & $0.363^{\star}$ & $0.405^{\star}$ & $0.506^{\star}$ & $0.609^{\star}$ \\
\hline All CD28+ & $0.261^{*}$ & $0.264^{*}$ & -0.07 & 0.143 & 0.078 & $0.441^{*}$ & 0.04 \\
\hline CD3-CD28+, PE & 0.09 & 0.12 & $0.44^{*}$ & $0.347^{*}$ & $0 \cdot 212^{*}$ & $0 \cdot 217^{*}$ & $0.499^{\star}$ \\
\hline CD3+CD28-, FITC & -0.118 & $-0.215^{\star}$ & $-0.23^{\star}$ & 0.131 & $0.174^{*}$ & $0.268^{*}$ & $0 \cdot 243^{*}$ \\
\hline CD3+CD28+, FITC & $-0.21^{*}$ & $-0.225^{\star}$ & $0.272^{*}$ & $-0.246^{\star}$ & $-0.442^{*}$ & $0.318^{*}$ & $0 \cdot 215^{\star}$ \\
\hline
\end{tabular}

Con, concanavalin, PE, phycoerythrin; FITC, fluorescein isothiosiyanate.

${ }^{*}$ Correlation coefficients are significantly different from zero $(P<0.05)$.

†For details of diets and procedures, see p. 180. 
animals as well as in human subjects. In support of this is the trend of higher mean CD28-PE but lower CD3-FITC fluorescence intensity in cells from $\mathrm{PF}$ than in those from $\mathrm{C}$ mice (Figs. 2-4). Moreover, in two mice, one ID and the other a $\mathrm{C}$, that were severely malnourished (due to long teeth and inability to eat enough feed (body weight about $11 \mathrm{~g}$, thymus weight about $10 \mathrm{mg}$ )), the mean CD28-PE fluorescence was 25 for the ID mouse and 131 for the C mouse. Mean CD3-FITC was 117 and 120 in the ID and the $\mathrm{C}$ mouse, respectively. However, 89.3 and $97 \%$ of thymocytes expressed CD3 receptor in the ID and C mouse, respectively, compared with roughly $25 \%$ for normal mice (Table 2). In contrast, only 25.47 and $49.97 \%$ of thymocytes from the C mouse and the ID mouse, respectively, expressed CD28 marker (instead of more than $90 \%$; see Table 2). Although a strong conclusion cannot be drawn based on two malnourished mice, this observation suggests that Fe deficiency combined with severe general malnutrition has a greater impact (reduction) on CD28 expression than either alone. The opposing effect of Fe deficiency on the expression of CD28 and CD3 leads us to speculate that perhaps during Fe deficiency the body develops a compensatory mechanism in an attempt to protect the capacity of T cells to be activated, undergo clonal expansion, and exert effector functions. Moreover, as suggested by positive correlation coefficients shown in Table 5, the degree of reduction of $\mathrm{CD} 28$ levels determines the severity of impairment of lymphocyte proliferation and probable associated functions.

Based on data summarized in Figs. 1 (C) and 3 (B), in addition to an effect of $\mathrm{Fe}$ status, CD28 expression is also influenced by splenomegaly. In rodents, when Fe is limiting, the spleen is also used as a site of haematopoiesis, which implies that mice with splenomegaly are diverting $\mathrm{Fe}$ toward erythrocyte production in the spleen, removing it from lymphocytes and other cells. This diversion is associated with reduced CD28 expression as well as lymphocyte proliferative responses to mitogens. Lower proliferative responses in ID mice with splenomegaly have been previously observed (Kuvibidila \& Sarpong, 1990).

Positive and significant correlations were observed between lymphocyte proliferative responses to mitogens and the percentages of CD3+ and CD28+ spleen cells and CD28-PE fluorescence intensity. In contrast, the percentage of CD3 - CD28+ spleen cells negatively correlated with spleen cell proliferative responses to mitogens. This observation is not surprising because in order for $\mathrm{T}$ lymphocytes to be activated and undergo proliferation, the TCR-CD3 complex is required for delivery of the so-called signal 1 to cells (June et al. 1994). Delivery of signal 1 to $\mathrm{T}$ lymphocytes leads to the hydrolysis of specific cell membrane phospholipids (phosphatidyl 4,5-bisphospahte), changes in free cytoplasmic $\mathrm{Ca}$ and protein kinase $\mathrm{C}$ activation; and these events are required for lymphocyte proliferation (Abbas et al. 1997).

Another interesting note is that the addition of antiCD28 to Con A- and anti-CD3-treated cultures increased lymphocyte proliferation in all groups. In fact, when total counts per min, instead of stimulation indexes, were used in statistical analysis of Con A-treated cultures, the differences between ID and either $\mathrm{C}$ or $\mathrm{PF}$ mice became small and non-significant at $P=0.05$ (no data shown). Anti-CD28 antibody is known to modulate (increase) the hydrolysis of phosphatidyl-inositol 4,5-bisphosphate in activated lymphocytes and to improve lymphocyte proliferative responses to mitogens (June et al. 1994). It has been previously reported that the hydrolysis of cell membrane phosphatidyl inositol 4,5 bisphosphate was reduced in spleen cells from ID mice, and this reduction may in part be related to low CD28 expression (Kuvibidila et al. 1998). Recently it has also been observed that Fe chelation increased the expression of CD80 and CD86 co-stimulatory markers on antigen-presenting cells; and these markers are the 'ligands' for the CD28 receptor (Kuvibidila \& Porretta, 2002). The percentage of spleen cells expressing CD80 receptor also increased in ID mice. It has also been observed that there was a negative correlation between the percentage of CD80+ spleen cells and lymphocyte proliferative responses to Con A and anti-CD3. By adding anti-CD28 to the culture medium, the interaction of CD28 and CD80 is reduced. It is therefore not surprising that anti-CD28 would significantly improve lymphocyte proliferative responses of ID spleen cells to Con A because the inhibitory effect of high percentages of CD80+ cells is abrogated. The present results therefore suggest that one mechanism by which Fe affects lymphocyte proliferation is by modulating the expression of the co-stimulatory molecules on both $\mathrm{T}$ cells and antigen-presenting cells.

In summary, our data suggest that Fe deficiency appears to down regulate the expression of CD28 but up regulate that of CD3 and this is the first time that such an observation has been reported. Our data also suggest that splenomegaly, but not thymus atrophy, tends to be associated with reduced expression of CD28 receptor in thymocytes and spleen cells, and in parallel reduces spleen cell proliferative responses to mitogens. Experiments are planned to determine whether the effects of ID are exerted at the level of gene transcription, stabilization of mRNA, translation of mRNA, or degradation of these receptors.

\section{Acknowledgements}

This work was supported by a special grant (Research Enhancement Funds) from the Dean of the Medical School, Louisiana State Health Excellence Fund 2000-05-06, and general funds from the Department of Pediatrics, Louisiana State University Health Sciences Center in New Orleans. The authors thank Dr Jay Kolls for his generosity for the use of the flow cytometry equipment in his laboratory.

\section{References}

Abbas AK, Lichtman AH \& Pober JS (1997) T lymphocyte antigen recognition and activation. In Cellular and Molecular Immunology, pp. 138-170 [AK Abbas, AH Lichtman and JS Pober, editors]. Philadelphia, PA: WB Saunders Company. Chandra RK \& Saraya AK (1975) Immunocompetence associated with iron deficiency. J Pediatr 86, 899-902. 
Dhur A, Galan P, Preziosi P \& Hercberg S (1991) Lymphocyte subpopulations in the thymus, lymph nodes, and spleen of iron-deficient and rehabilitated mice. J Nutr 121, 1418-1424.

Furukawa T, Naitoh Y, Kohno H, Tokinaga R \& Taketani S (1992) Iron deprivation decreases ribonucleotide reductase and DNA synthesis. Life Sci 50, 2059-2065.

Galan P, Thibault H, Preziosi P \& Hercberg S (1992) Interleukin-2 production in iron-deficient children. Biol Trace Elem Res 32, $421-426$.

Gross JA, Callas E \& Allison JP (1992) Identification and distribution of the co-stimulatory receptor $\mathrm{CD} 28$ in the mouse. J Immunol 149, 380-388.

Haq RU, Wereley JP \& Chitambar C (1995) Induction of apoptosis by iron deprivation in human leukemic CCCRI-CEM cells. Exp Hematol 23, 428-432.

Harding FA, McArthur JG, Gross JA, Raulet DH \& Allison JP (1992) CD28-mediated signalling co-stimulates murine T cells and prevents induction of anergy in T-cell clones. Nature 356, 607-609.

Hathcock KS, Laslo G, Pucillo C, Linsley P \& Hodes RJ (1994) Comparative analysis of B7-1 and B7-2 co-stimulatory ligands: expression and function. J Exp Med 180, 631-640.

Havran WL, Poenie M, Kimura J, et al. (1987) Expression and function of the CD3-antigen receptor on murine CD4+8+ thymocytes. Nature 330, 170-173.

Hileti D, Panayiotidis P \& Hoffbrand AV (1995) Iron chelators induce apoptosis in proliferating cells. Br J Haematol 89, $181-187$.

June CH, Bluestone JA, Nadler LM \& Thompson CB (1994) The B7 and CD28 receptor families. Immunol Today $\mathbf{1 5}$, $321-331$.

June CH, Ledbetter JA, Linsley PS \& Thompson CB (1990) Role of the CD28 receptor in T-cell activation. Immunol Today $\mathbf{1 1}$ 211-216.

Kemahli AS, Babacan E \& Cavdar AO (1988) Cell-mediated immune responses in children with iron deficiency and combined with iron and zinc deficiency. Research 8, 129-136.

Kuvibidila S, Dardenne M, Savino W \& Lepol F (1990) Influence of iron deficiency anaemia on selected thymus functions in mice: thymulin biological activity, T-cell subsets, and thymocyte proliferation. Am J Clin Nutr 51, 228-232.

Kuvibidila S, Nauss KM, Baliga BS \& Suskind RM (1983) Impairment of blastogenic response of splenic lymphocytes from iron deficient mice: in vivo repletion. Am J Clin Nutr 37, $15-25$.

Kuvibidila S \& Porretta C (2002) Differential effects of iron deficiency on the expression of CD80 and CD86 co-stimulatory receptors in mitogen-treated and untreated murine spleen cells. $J$ Cell Biochem 86, 571-582.
Kuvibidila S \& Sarpong D (1990) Mitogenic response of lymph nodes and spleen cells from mice with moderate and severe iron deficiency. Nutr Res 10, 195-210.

Kuvibidila SR, Baliga BS, Warrier RP \& Suskind RM (1998) Iron deficiency reduces the hydrolysis of cell membrane phosphatidyl-inositol 4,5 bis-phosphate during splenic lymphocyte activation in C57BL/6 mice. J Nutr 128, 1077-1083.

Kuvibidila SR, Kitchens D \& Baliga BS (1999) In vivo and in vitro iron-deficiency reduces protein kinase $\mathrm{C}$ activity and translocation in murine splenic and purified T cells. $J$ Cell Biochem 74, 468-478.

Kuvibidila SR, Porretta C, Baliga BS \& Leiva LE (2001) Reduced thymocyte proliferation but not increased apoptosis as a cause of thymus atrophy in iron-deficient mice. $\mathrm{Br} J$ Nutr 86, 157-162.

Latunde-Dada GO \& Young AP (1992) Iron deficiency and immune response. Scand J Immunol 11, Suppl., 207-209.

Looker AC, Dallman PR, Carroll MD, Gunter EW \& Johnson CL (1997) Prevalence of iron deficiency in the United States. JAMA 277, 973-976.

Munro HB (1993) Differences among group means: one way analysis of variance. In Statistical Methods for Health Care Research, 2nd ed., pp. 99-128 [HB Munro and EB Page, editors]. Philadelphia, PA: JB Lippincott Company.

Polson RJ, Jenkins R, Lombard M, et al. (1990) Mechanisms of inhibition of mononuclear cell activation by the iron-deficient desferrioxamine. Immunology 71, 176-181.

Rodak BF (1992) Routine laboratory evaluation of erythrocytes. In Clinical Hematology, Principles, Procedures, Correlations, pp. 107-123 [CA Lotspeich-Steininger, EA Stiene-Martin and JA Koepke, editors]. Philadelphia, PA: J.B. Lippincott Company.

Santos M \& De Sousa M (1994) In vitro modulation of T-cell surface molecules by iron. Cell Immunol 154, 498-506.

Shahinian T, Pfeffer K, Lee PK, et al. (1993) Differential T cell co-stimulatory requirements in CD28-deficient mice. Science 261, 609-612.

Thompson CB, Lindsten T, Ledbetter JA, et al. (1989) CD28 activation pathway regulates the production of multiple T-cellderived lymphokines/cytokines. Proc Natl Acad Sci USA 86, $1333-1337$.

Turka LA, Ledbetter JA, Lee K, June CH \& Thompson CB (1990) CD28 is an inducible T cell surface antigen that transduces a proliferative signal in $\mathrm{CD} 3+$ mature thymocytes. J Immunol 144, 1646-1653.

Turka LA, Linsley PS, Paine R III, et al. (1991) Signal transduction via $\mathrm{CD} 4, \mathrm{CD} 8$, and $\mathrm{CD} 28$ in mature and immature thymocytes: Implications for thymus selection. J Immunol 146, $1428-1436$. 